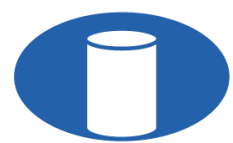

IBRACON

ORIGINAL ARTICLE

\title{
Correlation between diffusion coefficient values of chloride ions obtained through column and ion migration tests in cementitious matrices with varying contents of silica fume and mortar
}

\author{
Correlação entre valores de coeficiente de difusão de íons cloro obtidos por meio \\ de ensaios de coluna e de migração iônica em matrizes cimentícias com variados \\ teores de sílica ativa e de argamassa \\ Silas de Andrade Pinto ${ }^{\mathrm{a}}$ (D) \\ Sandro Lemos Machado ${ }^{\mathrm{b}}$ (D) \\ Daniel Véras Ribeiro ${ }^{\mathrm{b}}$

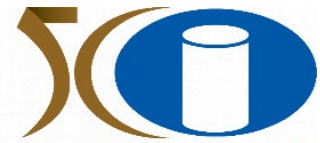 \\ YEARSIBRACON
}

${ }^{a}$ Universidade Federal da Bahia - UFBA, Programa de Pós-graduação em Engenharia Civil - PPEC, Salvador, BA, Brasil

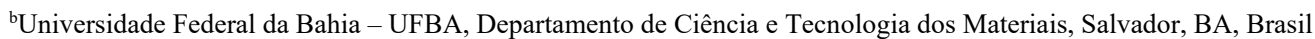

Received 21 January2021 Accepted 06 October 2021

\begin{abstract}
Corrosion is one of the main phenomena that lead to pathological manifestations in reinforced concrete structures under aggressive environments. with the chloride ion being the most responsible for its occurrence. In this way, understanding the transport mechanisms of this ion through the microstructure of the concrete is of fundamental importance to prevent or delay the penetration of these aggressive agents to guarantee a durable structure. In the literature, there are extensive studies concerning the diffusion of chlorides in concrete and the influence of pozzolanic additions in this mechanism. However, only a few correlate the different methods of analysis. This work aims to determine the chloride ion diffusion coefficients in concrete containing various levels of silica fume $(5 \%, 10 \%$, and $15 \%$ ) or varying the mortar content $(54 \%, 80 \%$, and $100 \%)$, and compares the results obtained through column tests and chloride migration tests. It was observed that, although the techniques used were quite distinct, the diffusion values obtained were similar, contributing to the validation of both techniques. Furthermore, the variation in the mortar ratio causes a reduction in the interfacial transition zone of coarse aggregate/mortars and an increase in the content of aluminates, which promotes a similar effect to the use of silica fume.
\end{abstract}

Keywords: Diffusion coefficient, concrete, mortar, chloride penetration, corrosion.

\begin{abstract}
Resumo: A corrosão é um dos principais fenômenos que geram manifestações patológicas nas estruturas de concreto armado em ambientes agressivos, sendo o íon cloro o maior responsável por sua ocorrência. Desta forma, entender os mecanismos de transporte deste íon através da microestrutura do concreto é de fundamental importância para impedir ou retardar a penetração destes agentes agressivos, visando garantir uma estrutura durável. Na literatura são vastos os estudos referentes à difusão de cloretos em concreto e a influência das adições pozolânicas neste mecanismo, entretanto, poucos correlacionam os diferentes métodos de análise. Assim, este trabalho visa determinar os coeficientes de difusão do íon cloro em concretos contendo diversos teores de adição de sílica ativa $(5 \%, 10 \%$ e $15 \%)$ ou com variação do teor de argamassa $(54 \%, 80 \%$ e 100\%), comparando os resultados obtidos por meio dos ensaios de migração iônica e de coluna. Observou-se que, apesar das técnicas utilizadas serem bastante distintas, os valores de coeficientes de difusão obtidos foram semelhantes, colaborando para a validação de ambas as técnicas. Além disso, a variação no teor de argamassa acarreta uma redução na zona de transição interfacial agregado graúdo/argamassas e um aumento no teor de aluminatos, o que promove efeito semelhante ao uso de sílica ativa.
\end{abstract}

Palavras-chave: Coeficiente de difusão, concreto, argamassa, penetração de cloreto, corrosão.

Corresponding author: Silas de Andrade Pinto. E-mail: silasandradepinto@gmail.com

Financial support: None.

Conflict of interest: Nothing to declare.

Data Availability: The data that support the findings of this study are available from the corresponding author, S. A. Pinto, upon reasonable request. 
How to cite: S. A. Pinto, S. L. Machado and D. V. Ribeiro, "Correlation between diffusion coefficient values of chloride ions obtained through column and ion migration tests in cementitious matrices with varying contents of silica fume and mortar," Rev. IBRACON Estrut. Mater., vol. 15, no. 3, e15307, 2022, https://doi.org/10.1590/S1983-41952022000300007

\section{INTRODUCTION}

Concrete is a durable material when well dosed and executed, however, concrete structures can deteriorate because of a series of deleterious mechanisms/reactions, bringing risks to the safety of users, besides the high costs of repairs.

The addition of supplementary materials with pozzolanic characteristics has been proving to be a good alternative for improve the concrete properties while also reducing cement consumption. The addition of silica fume (a byproduct with a high $\mathrm{SiO}_{2}$ content) to concrete allows the formation of secondary calcium silicate hydrates (C-S-H), which promote the pore sealing and discontinuity, making the passage of chloride ions more difficult and increasing their adsorption on the surface of the formed C-S-H [1]-[3].

According to Helene [4], chlorides penetrate through the pores, reaching the rebar and starting the corrosion. Thus, understanding how these ions diffuse inside the concrete can indicate the most appropriate material to be used.

Among the techniques extensively studied in the literature for chloride diffusion in concrete, are those used by Ribeiro et al. [5], Shackelford [6] and Andrade [7], based on ASTM C 1202 [8], NT BUILD 492 [9], ASTM C 1556 [10], and ASTM C 1543 [11]. These aim to accelerate the natural process of penetration of these ions and allow the determination not only of diffusion but also of other transport parameters such as tortuosity and mechanical dispersion.

The most usual techniques for determining the diffusion coefficient in concrete with a short test time apply a potential difference to accelerate the passage of chlorides. Andrade [7] considers that with potential differences of around 10 to $15 \mathrm{VDC}$, the migration phenomenon becomes predominant and the agitation caused in the particles is reduced, avoiding the problem of overheating in the methodology employed by ASTM C 1202 [8], which significantly affects the results obtained.

Other studies evaluate the penetration of harmful substances in porous media, based on the phenomenon of diffusion, such as the bulk diffusion test standardized by ASTM C 1556 [10] that provides results closer to reality and takes longer. In the evaluation of soils, for example, there are tests in which no application of electrical potential difference but rather of pressure in a fluid containing contaminant. Thus, the results obtained portray the phenomenon studied more adequately while not altering the agitation of particles due to application of potential difference. This method has already been applied in cementitious matrices in the studies performed by Vilasboas et al. [12] and Visudmedanukul [13], an adaptation of the NBR 10786 [14].

Given the several methodologies with different physical principles used to measure chloride diffusion, this work aims to provide correlations between the chloride migration test standardized by UNE 83987 [15] and the column test, to verify the accuracy and reliability of these methods when applied to cement matrices. Furthermore, the influence of silica fume addition and the variation of mortar content on the diffusion results will be evaluated. This is because the covering layer in reinforced concrete structures has a higher mortar content than the concrete inside them due to the compaction and finishing of the structural elements.

\section{MATERIALS AND EXPERIMENTAL PROGRAM}

\subsection{Materials}

In this research Portland CP V-ARI RS cement, standardized by NBR 16697 [16], fine quartz aggregate from the metropolitan region of Salvador, coarse aggregate, silica fume and CEMIX 2000 plasticizer admixture were used.

The concrete formulation 1.00: 1.83: 2.37: $\mathrm{x}: 0.60$ (cement: fine quartz aggregate: coarse aggregate: silica fume: water) was used. Its consistency, evaluated by slump test, was fixed at $180 \pm 10 \mathrm{~mm}$, and the content of silica fume added ranged from 5\% (5-SA), 10\% (10-SA) to 15\% (15-SA) by mass of cement. The water/cement ratio was fixed at 0.60 and the reference concrete produced had C30 class for Brazilian compressive strength, according to NBR 8953 [17].

The samples were also prepared with varying amounts of mortar, from $54 \%$ (reference), $80 \%$ (80-AG), to $100 \%$ (100-AG). The materials used in the preparation of the concrete are presented in Table 1. 
Table 1. Materials consumption per cubic meter of concrete.

\begin{tabular}{|c|c|c|c|c|c|c|c|}
\hline Mixture & $\begin{array}{l}\text { Cement } \\
\left(\mathrm{kg} / \mathrm{m}^{3}\right)\end{array}$ & $\begin{array}{c}\text { Fine quartz } \\
\qquad\left(\mathrm{kg} / \mathrm{m}^{3}\right)\end{array}$ & $\begin{array}{r}\text { Coarse } \\
\left(\mathrm{kg} / \mathrm{m}^{3}\right)\end{array}$ & $\begin{array}{l}\text { Silica fume } \\
\left(\mathbf{k g} / \mathrm{m}^{3}\right)\end{array}$ & $\begin{array}{c}\text { Water } \\
\left(\mathrm{kg} / \mathrm{m}^{3}\right)\end{array}$ & $\begin{array}{c}\text { Plasticizer } \\
\text { admixture } \\
\quad\left(1 / \mathbf{m}^{3}\right)\end{array}$ & $\begin{array}{c}\text { Compressive } \\
\text { strength at } 28 \\
\text { days (MPa) }\end{array}$ \\
\hline REF & 409.6 & 749.5 & 970.6 & - & 245.7 & - & $31.00 \pm 0.85$ \\
\hline $5-\mathrm{SA}$ & 407.6 & 745.9 & 965.9 & 20.5 & 244.5 & 0.48 & $31.35 \pm 1.62$ \\
\hline 10-SA & 404.1 & 739.5 & 957.6 & 41.0 & 242.4 & 1.46 & $35.44 \pm 0.67$ \\
\hline $15-\mathrm{SA}$ & 400.7 & 733.2 & 949.5 & 61.4 & 240.4 & 1.88 & $37.67 \pm 0.61$ \\
\hline 80-AG & 520.8 & 953.1 & 468.7 & - & 312.5 & - & $33.00 \pm 1.00$ \\
\hline $100-\mathrm{AG}$ & 622.5 & 1139.2 & - & - & 373.5 & - & $32.65 \pm 1.32$ \\
\hline
\end{tabular}

The cement has a specific gravity (helium gas pycnometry - AccuPyc II 1340 Micromeritics) equal to $3.14 \mathrm{~g} / \mathrm{cm}^{3}$, specific surface area BET (Gemini $2370 \mathrm{~V} 1.02$ - Micrometrics) equal to $7480 \mathrm{~cm}^{2} / \mathrm{g}$ and median equivalent diameter, $\mathrm{D}_{50}$ (Mastersizer 2000 Malvern), equal to $0.038 \mathrm{~mm}$.

The silica fume has a specific gravity equal to $2.35 \mathrm{~g} / \mathrm{cm}^{3}$, specific surface area equal to $14860 \mathrm{~cm}^{2} / \mathrm{g}$, and median equivalent diameter $\left(\mathrm{D}_{50}\right)$ equal to $0.0047 \mathrm{~mm}$.

Table 2 presents the chemical compositions of the cement and silica fume obtained by X-ray fluorescence spectrometry (Shimadzu XRF-1800). It can be observed that the chemical composition of the Portland cement contains the following main components, such as calcium oxide $(\mathrm{CaO})$, silica $\left(\mathrm{SiO}_{2}\right)$, alumina $\left(\mathrm{Al}_{2} \mathrm{O}_{3}\right)$, iron oxide $\left(\mathrm{Fe}_{2} \mathrm{O}_{3}\right)$, magnesium oxide $(\mathrm{MgO})$, a small percentage of sulfur trioxide $\left(\mathrm{SO}_{3}\right)$ and other impurities. The presence of alumina (4.84\%) is associated with $\mathrm{C}_{4} \mathrm{AF}$ (tetra-calcium aluminate iron) and $\mathrm{C}_{3} \mathrm{~A}$ (tricalcium aluminate) phases. According to Shi et al. [18], Ribeiro et al. [5], and Yue et al. [19], the aluminate content delays the non-steady state diffusion of chlorides due to the formation of chloroaluminates in the concrete microstructure, in particular Friedel's salt $\left(\mathrm{C}_{3} \mathrm{~A} \cdot \mathrm{CaCl}_{2} \cdot 10 \mathrm{H}_{2} \mathrm{O}\right)$.

Table 2. Chemical compositions of cement and silica fume used, in oxides.

\begin{tabular}{|c|c|c|c|c|c|c|c|c|c|c|c|}
\hline Content \% & $\mathrm{CaO}$ & $\mathrm{SiO}_{2}$ & $\mathrm{Al}_{2} \mathrm{O}_{3}$ & MgO & $\mathrm{Fe}_{2} \mathrm{O}_{3}$ & $\mathrm{SO}_{3}$ & $\mathrm{~K}_{2} \mathrm{O}$ & $\mathrm{Na}_{2} \mathrm{O}$ & $\mathrm{ZnO}$ & MnO & LOI. ${ }^{a)}$ \\
\hline Cement & 61.12 & 19.10 & 4.84 & 2.73 & 3.19 & 3.35 & 0.70 & 0.24 & - & - & 5.60 \\
\hline Silica fume & - & 79.00 & - & - & - & - & - & - & 16.86 & 4.14 & 4.40 \\
\hline
\end{tabular}

a) Loss on ignition.

In the chemical composition of the silica fume, mainly silica $\left(\mathrm{SiO}_{2}\right)$ is observed along with impurities such as zinc oxide $(\mathrm{ZnO})$ and manganese oxide $(\mathrm{MnO})$. However, the silica content in the silica fume used $(79 \%)$ is lower than the minimum content established by the Brazilian standard NBR 13956 [20], which is $85 \%$.

For the fine quartz aggregate, the specific gravity was determined according to NBR NM 52 [21]. The specific gravity of the coarse aggregate was determined according to NBR NM 53 [22]. Both aggregates were manually sieved, according to NBR NM 248 [23] to determine the granulometric composition. The results of this characterization can be seen in Table 3 .

Table 3. Physical characterization of aggregates and methods used.

\begin{tabular}{ccccc}
\hline Properties & Method & \multicolumn{2}{c}{ Fine quartz } & Coarse \\
\hline Specific gravity $\left(\mathrm{g} / \mathrm{cm}^{3}\right)$ & NM 52:2009 ${ }^{\text {a) }}$ and NBR NM 53:2009 b) & 2.66 & 2.87 \\
\hline Maximum diameter $(\mathrm{mm})$ & \multirow{2}{*}{ NBR NM 248:2003 } & 1.17 & 9.50 \\
\hline Fineness Modulus & & 1.32 & 5.72 \\
\hline
\end{tabular}

Obs.: ${ }^{\text {a) }}$ Method used to fine aggregate characterization; ${ }^{\text {b) }}$ Method used to coarse aggregate characterization.

\subsection{Physical characterization of concretes}

The water absorption by capillarity of each mix design was determined according to the procedure according to NBR 9779 [24]. Three cylindrical specimens $(\phi 10 \mathrm{~cm}$ x $20 \mathrm{~cm})$ were used, and after 28 days of curing, they were dried in an oven to a constant mass. Then, the specimens were positioned in a container with a water slide equal to $5 \pm 1 \mathrm{~mm}$ above the lower face, and the masses were monitored until equilibrium. 
To calculate the sorptivity (S), the slope of the line generated by the results of water absorption $\left(\mathrm{A}, \mathrm{kg} / \mathrm{m}^{2}\right)$ as a function of the square root of time $(\mathrm{t})$ is used, according to Equation 1.

$A=b+S \cdot \sqrt{t}$

This test depends directly on the radius of the pores in the material, so the sorptivity is an indication of the diffusion results and consequently the durability of the concrete.

After 28 days, three specimens were tested using the Archimedes principle, according to NBR 9778 [25]. The specimens were dried in an oven and their dry masses $\left(\mathrm{M}_{\mathrm{d}}\right)$ were determined, then the samples were immersed in water for $72 \mathrm{~h}$ for complete saturation of the existing open porosity, and the immersed $\left(\mathrm{M}_{\mathrm{i}}\right)$ and wet $\left(\mathrm{M}_{\mathrm{w}}\right)$ masses were determined. The apparent porosity $\left(\mathrm{P}_{\mathrm{A}}\right)$ and density $\left(\mathrm{D}_{\mathrm{A}}\right)$ were calculated based on Equations 2 and 3, respectively, with $\rho_{\mathrm{L}}$ being the density of the liquid (in this case, water, equal to $1 \mathrm{~g} / \mathrm{cm}^{3}$ ).

$P_{A}=100 \cdot \frac{M_{w}-M_{d}}{M_{w}-M_{i}}$

$D_{A}=\rho_{L} \cdot \frac{M_{d}}{M_{w}-M_{i}}$

\subsection{Chloride Migration Assessment in Concrete}

\subsubsection{Sample selection and calibration of conductivity curve}

The selection of representative specimens of each composition is complicated because of the great diversity of elements (and their relative ratios). Therefore, an adaptation of ASTM E 562 [26] proposed by Ribeiro [5] was used. According to this standard, the relative amount (\%) of a certain target phase (coarse aggregate, in this work) can be estimated by overlaying a grid on the specimen and then counting the intersecting nodes in the middle and edges of the target phase. In this example, which is illustrated in Figure 1, the grid contains 38 nodes, and intersections with gravel correspond to 15 points (12 in the middle $+6 \cdot 0.5$ at the edges). Thus, $15 / 38$ would yield an estimated $39.5 \mathrm{vol} . \%$ of gravel in the sample.

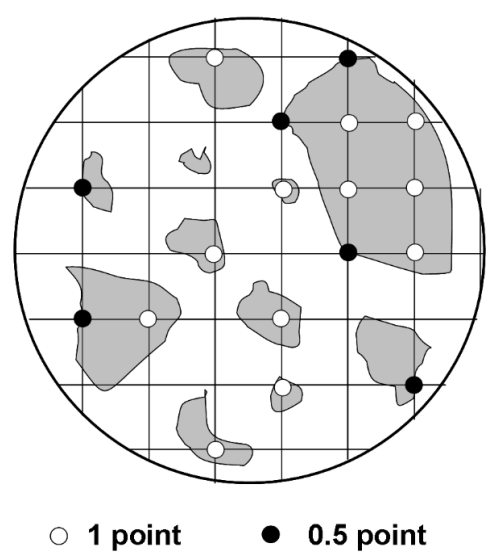

Figure 1. Process of sample selection and phase quantification for chloride migration tests, adapted from ASTM E 562-02 [5].

Prior to conducting the chloride migration tests, the specimens were submerged in distilled water for $24 \mathrm{~h}$, as in Ribeiro et al. [5], Castellote et al. [27], and Amorim Júnior et al. [28] studies, to saturate the specimens so that only the ionic migration occurred during the test. During the tests, the electrical conductivity of the anodic cell solution was monitored daily using a portable pentype digital conductivity meter (Homis Model 42). The concentration of chlorides in the anodic cell was estimated using the equation $\mathrm{y}=132.88 \cdot \mathrm{x}\left(\mathrm{R}^{2}=0.9969\right)$, where $\mathrm{x}$ is the conductivity in $\mathrm{mS} / \mathrm{cm}$ and $\mathrm{y}$ is the concentration $\mathrm{f}^{-} \mathrm{Cl}^{-}$in $\mathrm{mol} / \mathrm{l}$. This mathematical expression was obtained experimentally (Figure 2) with $\mathrm{NaCl}$ solutions, at $20^{\circ} \mathrm{C}$. 


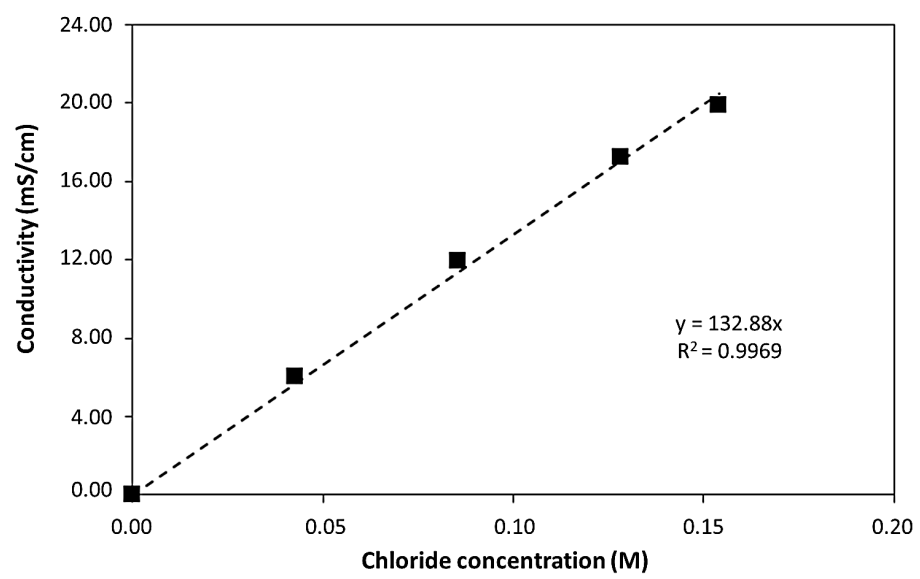

Figure 2. Experimental relationship between electrical conductivity and chloride concentration in the anodic compartment, which initially contains distilled water.

\subsubsection{Accelerated migration test}

This test uses the principle of applying a potential difference between two cells, one filled with a solution containing a contaminant $(\mathrm{NaCl})$ and the other cell with distilled water. After 28 days in water, the specimen was prepared and positioned between the two cells as shown in Figure 3. In this method, the migration occurs due to the application of an electrical potential difference of 12 VDC through the electrodes contained in the cells.

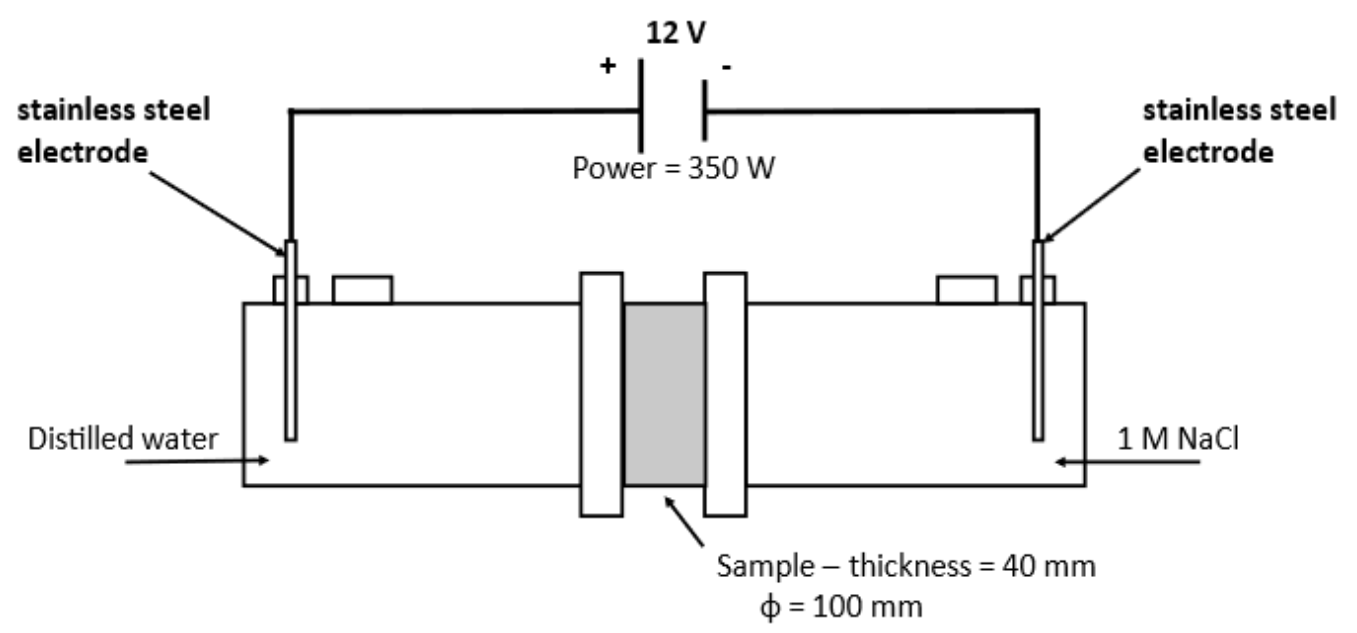

Figure 3. Schematic drawing of the chloride migration test apparatus.

For this test, a chloride migration apparatus was used, as suggested by Andrade [7] and developed by Ribeiro et al. [5], following the procedures presented in UNE 83987 [15]. The tests were carried out on three specimens of each series, each with a thickness of $40 \mathrm{~mm}$, extracted from the central region of the cylindrical specimens $(\phi=100 \mathrm{~mm}, \mathrm{~h}=200 \mathrm{~mm})$, using a diamond disc cutting machine.

At the start of the test, the concentration of chlorides passing through the anodic cell is not a constant flow, due to adsorption on the capillary walls, and the reactions of these ions with the aluminates present in the cement and in the mineral additions. These form a Friedel's salt at a non-steady state. When the pores are saturated and the reserves of aluminates depleted, the flow becomes constant, entering a steady-state condition.

Thus, the time required to start the stationary phase is called time lag $(\tau)$ and is obtained through the intersection between the extension of the straight line that characterizes the steady-state condition and the abscissa axis (time), according to Figure 4. 


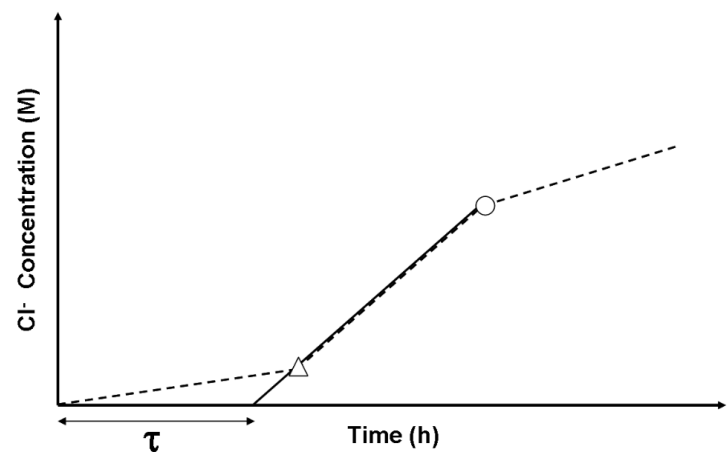

Figure 4. Experimental determination of the time lag $(\tau)$; onset $(\Delta)$ and end $(\circ)$ of the steady-state diffusion stage (adapted from Castellote et al. [24]).

The diffusion coefficient in the transient or non-steady state $\left(\mathrm{D}_{\mathrm{ns}}\right)$, in $\mathrm{cm}^{2} / \mathrm{s}$, can be measured, based on migration testing, using Equations 4 and 5, proposed by Castellote et al. [27]. The steady-state diffusion coefficient $\left(\mathrm{D}_{\mathrm{s}}\right)$, in $\mathrm{cm}^{2} / \mathrm{s}$, was calculated applying the modified Nernst-Plank equation (Equation 6).

$D_{n s}=\frac{2 \cdot l^{2}}{\tau \cdot v^{2}} \cdot\left[u \cdot \operatorname{coth} \frac{v}{2}-2\right]$

$\mathrm{v}=\frac{z \cdot e \cdot \Delta \Phi}{\mathrm{k} \cdot \mathrm{T}}$

$D_{s}=\frac{j_{C l} \cdot R \cdot T \cdot l}{\mathrm{z} \cdot \gamma \cdot \mathrm{F} \cdot C_{C l} \cdot \Delta \Phi}$

Where $l$ is the thickness of the sample (cm), $\tau$ is the time lag (s), $z$ is the valence of the ions (equal to 1 ), $e$ is the electric charge of an electron $\left(1.6 \cdot 10^{-19} \mathrm{C}\right), \Delta \Phi$ is the voltage $(\mathrm{V}), k$ is the Boltzmann constant $\left(1.38 \cdot 10^{-23} \mathrm{~J} / \mathrm{K}\right)$, and $T$ is the absolute temperature. Furthermore, $j_{C l}$ is the ion flux $\left[\mathrm{mol} /\left(\mathrm{s.cm}^{2}\right)\right], R$ is a constant $[1.9872 \mathrm{cal} /(\mathrm{mol} \cdot \mathrm{K})], F$ corresponds to the Faraday constant [23063 cal/(volt. eq)]. Finally, $C_{C l}$ is the chloride concentration in the cathode cell $\left(\mathrm{mol} / \mathrm{cm}^{3}\right)$, and $\gamma$ is a constant of activity coefficient $\left(0.657\right.$ for $\left.\mathrm{Cl}^{-}\right)$.

\subsubsection{Column test}

The column test aims to determine the transport parameters that interfere with the diffusion of contaminants by porous media in controlled laboratory conditions [6], [29] which reflect the real situation. This technique is extensively used to understand soil/contaminant interaction, but recently it has been applied in Portland cement matrices, such as soil-cement [13] and in mortars and concrete [12].

According to Vilasboas [12], Nascentes [30], and Bear [31] in the modeling of the transport of solutes by the column test, in which liquid flow occurs, it is not common to separate the diffusion process (D) from the dispersion process $\left(D_{m}\right)$. They are treated in a combined way to define the parameter called hydrodynamic dispersion $\left(D_{h}\right)$, as presented in Equation 7.

$D_{h}=D+D_{m}$

Dispersion-diffusion (D) is due to the flow of a chemical species in solution, however, when diffusion occurs inside the pores of the materials, it is reduced due to the tortuosity of the pores (w) and is expressed by Equation 8 [32]. The maximum value for tortuosity is equal to 1 because the maximum diffusion will happen when there are no blockages.

$D=w \cdot D_{C l}$ 
Mechanical dispersion $\left(D_{m}\right)$ is the process of mixing the contaminant resulting from the variation in the percolation speed of the fluid, which occurs in the interconnected pores. The contaminants percolate at different speeds depending on the tortuosity, friction, and size of the pores [33]. The mechanical dispersion is expressed by means of Equation 9.

$D_{m}=\alpha \cdot v s$

Where $\alpha$ is the mechanical dispersion coefficient $(\mathrm{cm})$, vs is the solvent flow velocity $(\mathrm{cm} / \mathrm{s})$.

It can be noted that only the diffusion coefficient (D) can be correlated with the stationary diffusion $\left(\mathrm{D}_{\mathrm{s}}\right)$ obtained from the migration test. This is because diffusion considers ionic movement without water flow, there being only the tortuosity of the matrix pores as blockages [31]. Moreover, the diffusion coefficient in the nonsteady state $\left(\mathrm{D}_{\mathrm{ns}}\right)$, obtained from the ion migration test, does not present a theoretically similar parameter in the column test.

To carry out this test, a column testing apparatus like the model indicated for concrete permeability tests was used, standardized by NBR 10786 [14], and used by Vilasboas et al. [12]. Three samples with $100 \mathrm{~mm}$ diameter and $40 \mathrm{~mm}$ thickness were taken from the central region of the cylindrical specimens using a diamond disc cutting machine.

Before the diffusion tests, the samples remained immersed in distilled water for 24 hours, like the conditioning performed for the accelerated migration test.

The test consists of forcing the contaminant fluid through the samples by applying a pressure $\left(8 \mathrm{kgf} / \mathrm{cm}^{2}\right)$. To ensure lateral sealing of the specimens, pressurized $\mathrm{N}_{2}$ is supplied, filling the outer part of the specimen and compressing a latex membrane that surrounds it. The same pressure as the $\mathrm{N}_{2}$ is supplied to the reservoirs of the solution, however, because they are located at a lower elevation than the nitrogen cylinder, the solution leaving the reservoirs has a lower pressure when reaching the samples, due to the loss of load. Thus, the external pressure is higher than the internal pressure, ensuring lateral sealing. The diagrams of the system, chambers, and apparatus can be seen in Figures 5 and 6, respectively.

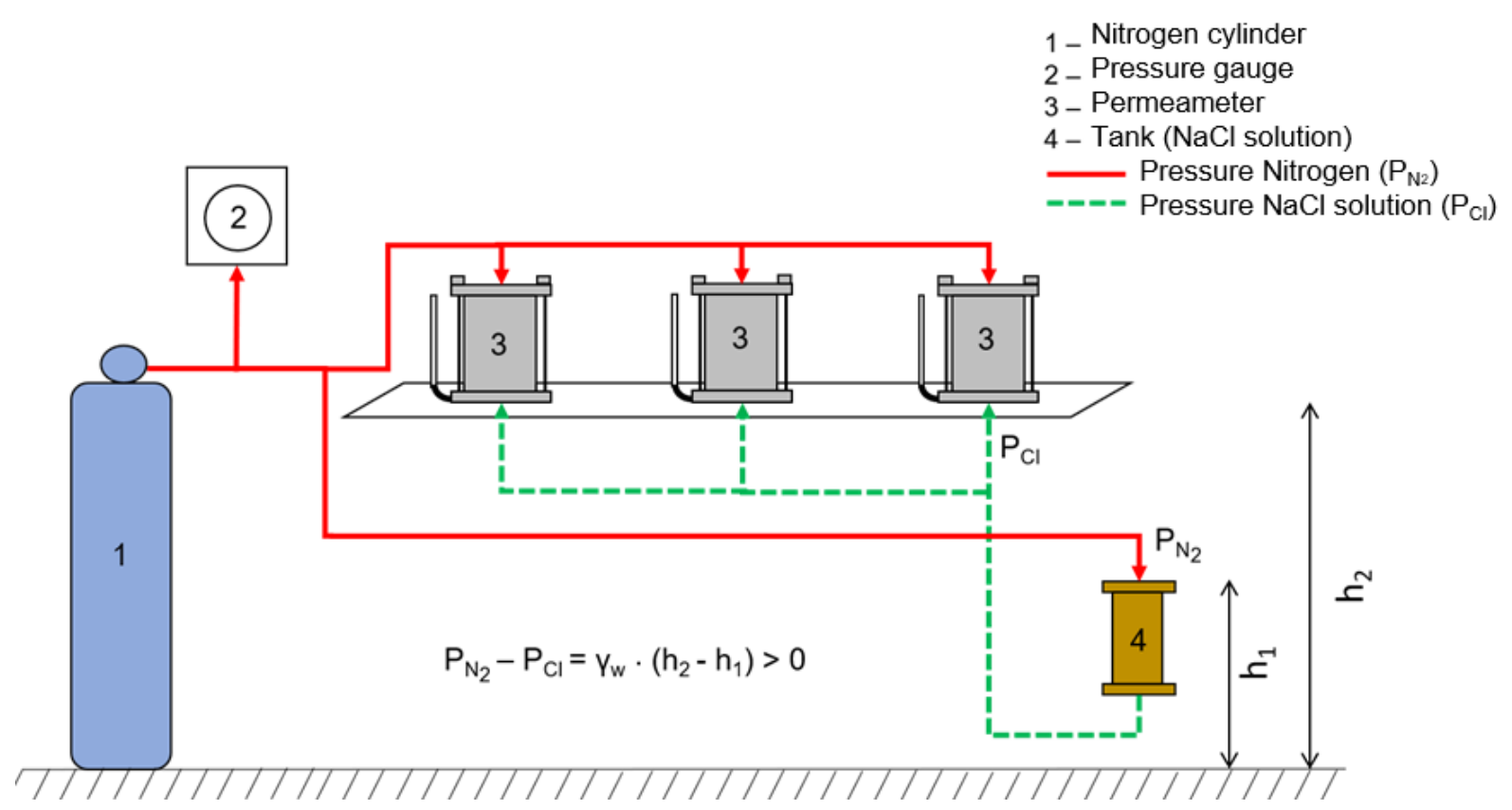

Figure 5. Schematic drawing of the column test apparatus. 


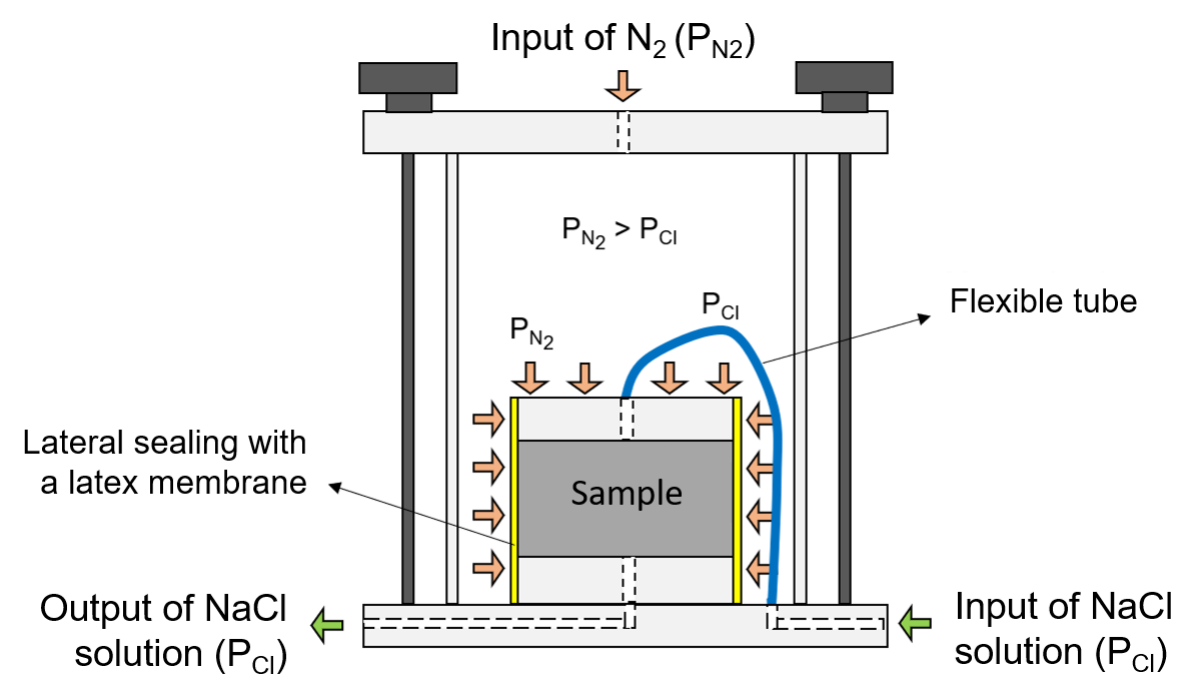

Figure 6. Schematic drawing of internal operation of the permeameter.

During the test, the solution that has percolated through the specimen is collected and its volume and chloride concentration over time is measured. Then an $\mathrm{N}_{\mathrm{VP}} \mathrm{X} C / \mathrm{C}_{0}$ graph is drawn with $\mathrm{N}_{\mathrm{VP}}$ being the number of porous volumes that represents the time that the volume percolated through the sample filling its pores, determined by Equation 10 .

$\mathrm{N}_{V P}=\frac{V_{o l}}{\mathrm{n}}$

Where $\mathrm{V}_{\mathrm{ol}}$ is the accumulated volume of the solution passing through the test $\left(\mathrm{cm}^{3}\right)$ and $\mathrm{n}$ is the porosity of the specimen $\left(\mathrm{cm}^{3}\right)$.

Based on experimental points, a theoretical curve is adjusted, based on Equation 11, modified by Freeze and Cherry [34], to obtain a maximum determination coefficient $\left(\mathrm{R}^{2}\right)$.

$\frac{C(x, t)}{c_{0}}=\frac{1}{2}\left[\operatorname{erfc}\left(\frac{R_{d} \cdot x-v_{s} \cdot t}{2 \sqrt{R_{d} \cdot D_{h} \cdot t}}\right)+\exp \left(\frac{v_{s} \cdot x}{D_{h}}\right) \operatorname{erfc}\left(\frac{R_{d} \cdot x+v_{s} \cdot t}{2 \sqrt{R_{d} \cdot D_{h} \cdot t}}\right)\right]$

Where $C(x, t)$ is the concentration at a depth $x$ and time $t$ desired, $C_{o}$ is the initial concentration, $R_{d}$ is the retardation factor $(\geq 1), D_{h}$ is the hydrodynamic dispersion, $v_{s}$ is the velocity of fluid percolation.

The retardation factor $\left(\mathrm{R}_{\mathrm{d}}\right)$ is directly influenced by the adsorption capacity of the porous media, which is related to its the specific surface and valence and size of the solute ions. Coarser soil fractions, for instance, tend to present $R_{d}$ close to unity (i.e., are unable to retain appreciable amounts of solute on their solid surfaces) [35]. This parameter has conceptual similarity with the time lag obtained with the migration test performed according to UNE 83987 [15], since both quantify the capacity of the matrix to retain a given substance.

\section{RESULTS AND DISCUSSION}

\subsection{Physical characterization of concretes}

It can be observed that the porosity of the matrix decreased as the silica fume content increased (Figure 7). This is due to the pozzolanic reaction, a consequence of the presence of amorphous silica in the silica fume used, which promotes the formation of hydrated calcium silicate (C-S-H). In addition, the silica fume has a filler effect caused by particles that do not react with $\mathrm{Ca}(\mathrm{OH})_{2}$ and that contribute to the filling of voids, allowing better packaging of particles [36], [37]. By varying the mortar content, an increase in the porosity of the specimens was noted because mortar is more porous than coarse aggregate. 


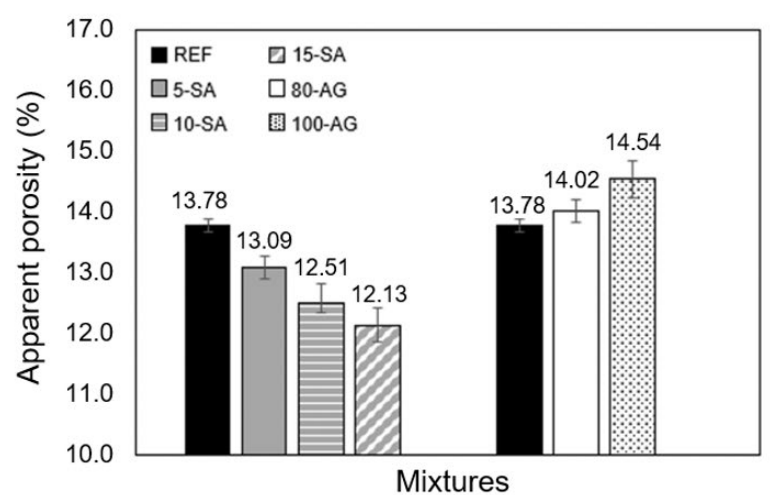

(A)

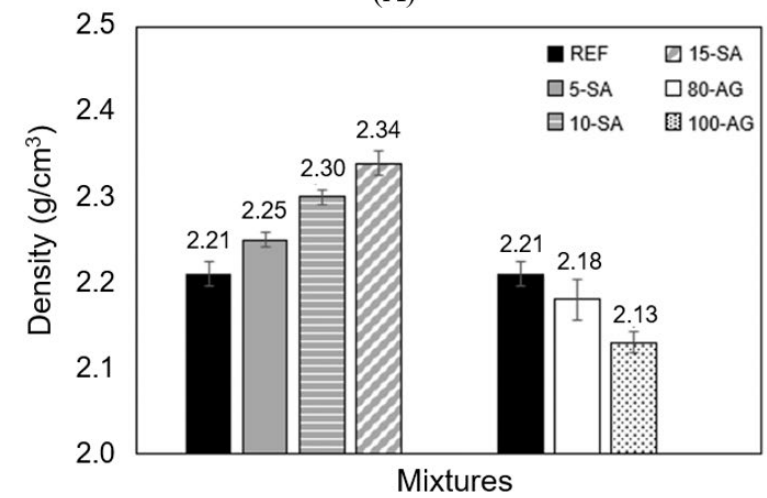

(B)

Figure 7. (A) Apparent porosity and (B) density of concretes with different silica fume and mortar contents.

The sorptivity of the concrete with varying contents of silica fume and mortar are presented in Figure 8 . There is an increase in the rate of sorptivity of the concrete with the addition of higher contents of silica fume, up to the limit content of $10 \%$. This is due to a reduction in the pore diameter, promoting an increase in the number of capillary pores and in turn increasing the water capillary absorption rate. With the addition of $15 \%$ of silica fume, there was a stabilization of the sorptivity due to a possible blocking and disconnection of the capillary pores [38].

There was also a reduction in the sorptivity in the specimens due to the increase in the mortar contents, however, this reduction was not statistically significant. This may have been due to the packaging factor of the system being more efficient when there are grains of different sizes, generating less porosity with the presence of the coarse aggregate. Furthermore, Scrivener et al. [39] reported that an increase in the content of fine quartz aggregate in the matrix makes the transition zone more tortuous. As a result, the capillary suction is made harder by the lack of a perfectly linear path, physically blocking the displacement of water.

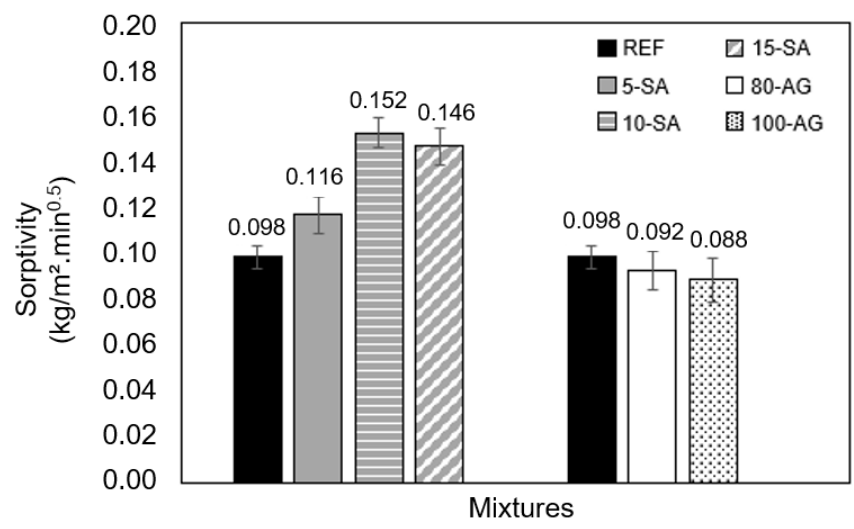

Figure 8. Sorptivity of the studied concretes. 


\subsection{Chloride Migration Assessment in Concrete}

\subsubsection{Accelerated migration test}

Figure 9 shows the evolution of chloride concentration in the anodic chamber of reference concrete samples and those containing additions of $5 \%, 10 \%$, and $15 \%$ silica fume. The concentration of chloride ions $\left(\mathrm{Cl}^{-}\right)$increases with time, because of the application of the applied electric voltage, forcing these ions to migrate towards the positive pole of the system.

As more silica fume is added to the cement matrix, a deviation in the chloride concentration curve as a function of time can be seen to the right. This represents an increase in the time lag value up to $126 \%$ for a $15 \%$ addition of silica fume. Therefore, in concrete containing silica fume, the chlorides take longer to saturate and to cross the covering layer of the concrete, reaching the rebar and depassivating it. In the non-steady state condition, the solution containing chlorides adsorbs to the walls of the interconnected capillary pores and reactions between the chlorides and the aluminates present in the cement form Friedel's salt [40].

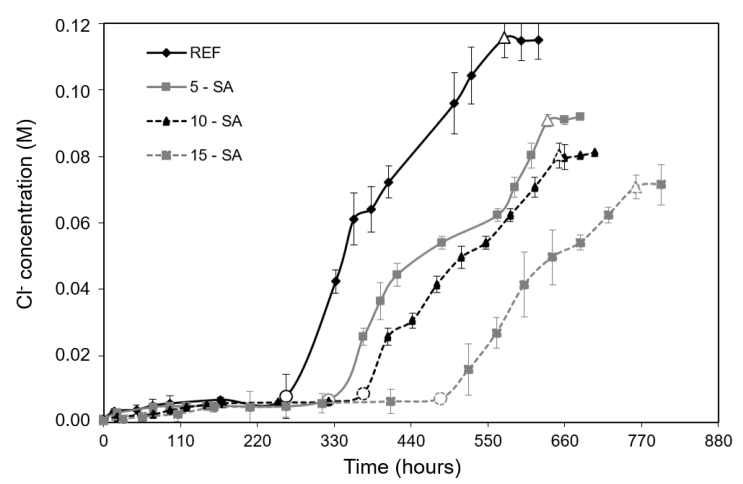

Figure 9. Chloride concentration in the anodic cell solution as a function of time for the concrete specimens with $0 \%, 5 \%, 10 \%$, and $15 \%$ of silica fume ( $O=$ beginning of steady state and $\Delta=$ end of steady state).

After the start of the steady-state condition, the flow of ions $\left(\mathrm{j}_{\mathrm{Cl}}\right)$ becomes constant until the stability of the chloride concentration is reached [27]. For samples with varying silica fume contents, there is a reduction in the flow of ions. When present in the concrete (this can be visualized by the reduction in the inclination of the straight line in the steadystate condition), the addition of silica fume confers greater durability of the concrete as well as resistance to the action of chlorides. This finding is in line with the results obtained in studies by Aitcin [41] and Ribeiro et al. [5], which showed that mineral additions reduce the movement of chlorides in the concrete microstructure due to the better distribution of pore diameters, resulting from the pozzolanic reactions, which difficult the ionic movement.

Figure 10 shows the evolution of chloride concentration in the anodic chamber when reference concrete samples are evaluated (with a mortar content equal to $54 \%$ ) and with mortar contents equal to $80 \%$ and $100 \%$.

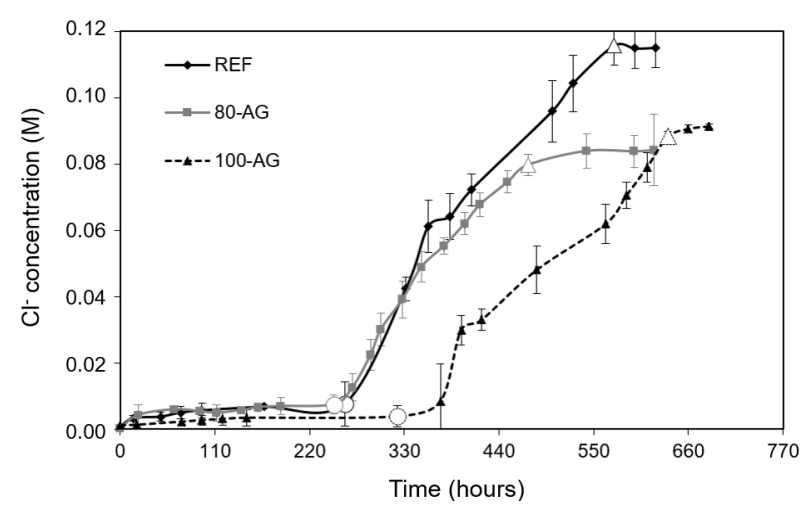

Figure 10. Chloride concentration in the anodic cell solution as a function of time for the concrete specimens with different mortar content $(\mathrm{O}=$ beginning of steady state and $\Delta=$ end of steady state). 
An approximate $49 \%$ increase in the time lag was observed by reducing the consumption of coarse aggregate, due to the higher consumption of cement and, consequently, higher content of aluminates. With an increase in the mortar content, the coarse aggregate/paste interface is reduced until non-existent (samples containing 100\% mortar), which alters the connectivity of the pores and leads to an increase in tortuosity, making the passage of chloride ions difficult. These interfacial transition zones are of great importance in durability studies because it is through them that the preferential penetration of chloride ions occurs [5], [18].

In addition, due to the reduction in the aggregate/paste transition zone from a higher mortar content, the chloride flow is also reduced. This is because the solution containing chlorides will preferentially pass through this interface [42], [43] because of the change in the tortuosity of the pores, as previously discussed.

Furthermore, the diffusion coefficients in the steady and non-steady states obtained from concrete with different contents of silica fume and mortar, respectively, are shown in Tables 4 and 5. The results of the non-steady state diffusion coefficient $\left(\mathrm{D}_{\mathrm{ns}}\right)$ were classified based on the limits established by Nilsson et al. [44] which refer to the $\mathrm{D}_{\mathrm{ns}}$ obtained by the NT Build 492 test [9]. According to Guignone et al. [45], the $\mathrm{D}_{\mathrm{ns}}$ values obtained by the method of UNE 83987 [15] and NT Build 492 [9] show similarities. However, according to Sell Júnior et al. [46], the difference between the diffusion coefficients determined by these methods is greater when evaluating the concretes that have greater permeability. However [28], [47], used this classification in articles that evaluated the chloride diffusion by the method of UNE 83987 [15].

Table 4. Classification of concretes with different silica fume contents as to resistance to chloride penetration, according to the limits established by Nilsson et al. [44].

\begin{tabular}{|c|c|c|c|c|c|}
\hline Mixture & Time lag (h) & $\begin{array}{c}\text { Ion flow } \\
\left(10^{-10} \mathbf{~ m o l} / \mathbf{s} \cdot \mathrm{cm}^{2}\right)\end{array}$ & $\begin{array}{c}D_{\mathrm{s}} \\
\left(10^{-8} \mathrm{~cm}^{2} / \mathrm{s}\right)\end{array}$ & $\begin{array}{c}D_{\mathrm{ns}} \\
\left(10^{-8} \mathrm{~cm}^{2} / \mathrm{s}\right)\end{array}$ & $\begin{array}{l}\text { Resistance to chloride } \\
\text { penetration }\end{array}$ \\
\hline REF & 204.22 & 5.91 & 1.48 & 9.33 & \multirow{3}{*}{$\begin{array}{c}\text { High } \\
\left(5 \cdot 10^{-8} \mathrm{~cm}^{2} / \mathrm{s}<\mathrm{D}_{\mathrm{ns}}<10 \cdot 10^{-8}\right. \\
\left.\mathrm{cm}^{2} / \mathrm{s}\right)\end{array}$} \\
\hline 5-SA & 298.00 & 3.41 & 0.85 & 6.30 & \\
\hline $10-\mathrm{SA}$ & 372.05 & 3.68 & 0.92 & 5.05 & \\
\hline $15-\mathrm{SA}$ & 461.12 & 3.92 & 0.98 & 4.08 & $\begin{array}{c}\text { Very high } \\
\left(2.5 \cdot 10^{-8} \mathrm{~cm}^{2} / \mathrm{s}<\mathrm{D}_{\mathrm{ns}}<5 \cdot 10^{-8}\right. \\
\left.\mathrm{cm}^{2} / \mathrm{s}\right)\end{array}$ \\
\hline
\end{tabular}

Table 5. Classification of concretes with different mortar contents as to resistance to chloride penetration, according to the limits established by Nilsson et al. [44].

\begin{tabular}{|c|c|c|c|c|c|}
\hline Mixture & Time lag (h) & $\begin{array}{c}\text { Ion flow } \\
\left(10^{-10} \mathrm{~mol} / \mathrm{s} \cdot \mathrm{cm}^{2}\right)\end{array}$ & $\begin{array}{c}D_{\mathrm{s}} \\
\left(10^{-8} \mathrm{~cm}^{2} / \mathrm{s}\right)\end{array}$ & $\begin{array}{c}D_{\mathrm{ns}} \\
\left(10^{-8} \mathrm{~cm}^{2} / \mathrm{s}\right)\end{array}$ & $\begin{array}{l}\text { Resistance to chloride } \\
\text { penetration }\end{array}$ \\
\hline REF & 204.22 & 5.91 & 1.48 & 9.33 & \multirow{3}{*}{$\begin{array}{c}\text { High } \\
\left(5 \cdot 10^{-8} \mathrm{~cm}^{2} / \mathrm{s}<\mathrm{D}_{\mathrm{ns}}<10 \cdot 10^{-8}\right. \\
\left.\mathrm{cm}^{2} / \mathrm{s}\right)\end{array}$} \\
\hline $80-\mathrm{AG}$ & 218.03 & 2.88 & 0.72 & 8.61 & \\
\hline $100-\mathrm{AG}$ & 304.04 & 4.14 & 1.03 & 6.17 & \\
\hline
\end{tabular}

Some researchers [47]-[49] have also observed that the addition of $10 \%$ silica fume in relation to the mass of cement promoted better refinement of the microstructure. However, according to the results presented in Table 5, it was found that this improvement also occurred with an increase in the mortar content.

\subsubsection{Column test}

The retention curves from the column test were plotted, presenting the mean curves as well as the standard deviation existing at all points on the curve (Figure 11). The retardation factor $\left(\mathrm{R}_{\mathrm{d}}\right)$ was determined based on the curve that correlates the relative concentration of chloride ions $\left(\mathrm{C} / \mathrm{C}_{0}\right)$ and the number of porous volumes $\left(\mathrm{N}_{\mathrm{VP}}\right)$, which is a method used by Vilasboas et al. [12]. The retardation factor $\left(\mathrm{R}_{\mathrm{d}}\right)$ corresponds to the number of pore volumes equivalent to a 
relative concentration of $50 \%$. The other parameters were identified through the interaction of these coefficients to adjust a curve to present a higher correlation coefficient $\left(\mathrm{R}^{2}\right)$, from the experimental points obtained.

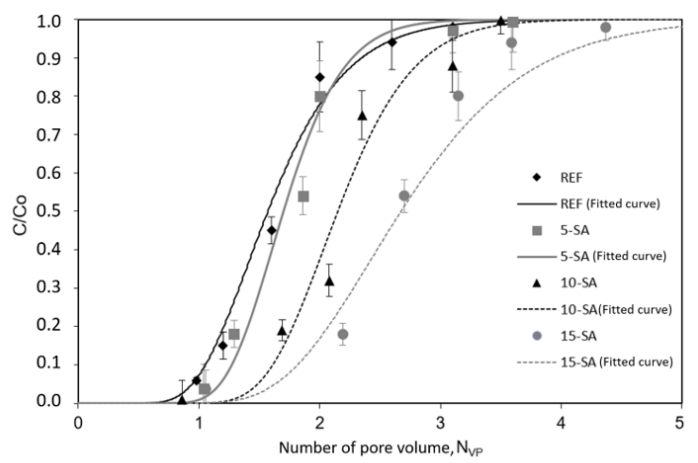

(A)

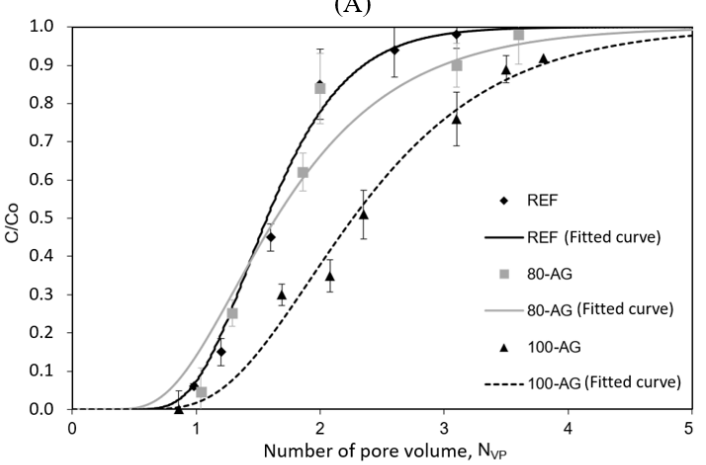

(B)

Figure 11. Relative chloride concentration curve in the concrete column test with different content of (A) silica fume and (B) mortar.

Table 6 shows the average transport parameters obtained by adjusting the column test data for the different types of concrete tested.

Table 6. Summary of transport parameters determined by the column test in concretes with different silica fume and mortar contents.

\begin{tabular}{|c|c|c|c|c|c|c|c|}
\hline Mixture & $\begin{array}{l}\mathbf{R}_{\mathbf{d}} \\
(-)\end{array}$ & $\begin{array}{c}V_{s} \\
\left(10^{-6} \mathrm{~cm} / \mathrm{s}\right)\end{array}$ & $\begin{array}{c}\alpha \\
(\mathbf{c m})\end{array}$ & $\begin{array}{c}D_{m} \\
\left(10^{-7} \mathrm{~cm}^{2} / \mathrm{s}\right)\end{array}$ & $\begin{array}{l}\mathbf{w} \\
(-)\end{array}$ & $\begin{array}{c}D^{1)} \\
\left(10^{-8} \mathrm{~cm}^{2} / \mathrm{s}\right)\end{array}$ & $\mathbf{R}^{2}$ \\
\hline REF & 1.65 & 4.29 & 0.20 & 8.58 & 0.00100 & 1.60 & 0.98 \\
\hline $5-\mathrm{SA}$ & 1.70 & 3.04 & 0.10 & 3.04 & 0.00040 & 0.64 & 0.94 \\
\hline $10-\mathrm{SA}$ & 2.15 & 1.56 & 0.09 & 1.40 & 0.00054 & 0.86 & 0.96 \\
\hline 15-SA & 2.80 & 2.32 & 0.07 & 9.24 & 0.00062 & 0.99 & 0.97 \\
\hline 80-AG & 1.83 & 3.12 & 0.26 & 8.11 & 0.00045 & 0.72 & 0.93 \\
\hline $100-\mathrm{AG}$ & 2.45 & 1.56 & 0.18 & 2.81 & 0.00064 & 1.02 & 0.93 \\
\hline
\end{tabular}

Obs.: ${ }^{1)}$ Using the diffusion of the chloride ion in water $\left(\mathrm{D}_{\mathrm{cl}}=1.60 \cdot 10^{-5} \mathrm{~cm}^{2} / \mathrm{s}\right)$.

The values of $R_{d}$, which represents a parameter like the time lag $(\tau)$ of the ionic migration test, are in the range found by Vilasboas et al. [12] for concrete and mortar tests (1.40 to 3.50), and by Visudmedanukul [13] in soil-cement tests (1.03 to 2.77). As well as the time lag $(\tau)$ of the ionic migration test, the $\mathrm{R}_{\mathrm{d}}$ indicates the retention capacity of the substances.

This behavior is also reflected in the diffusion coefficients found for these materials because this is related to a constant (diffusion of chloride in water, equal to $1.60 \cdot 10^{-5} \mathrm{~cm}^{2} / \mathrm{s}$ [12], [51]) multiplied by the tortuosity factor of each analyzed sample $\left(\mathrm{w} \cdot \mathrm{D}_{\mathrm{Cl}}\right)$.

The results obtained corroborate those obtained by Shekarchi et al. [49], who verified small changes in the chloride diffusion coefficients in concrete with silica fume contents higher than $7.5 \%$, when exposed in a maritime zone. 
Although different methods were used in relation to ionic migration, the diffusion values obtained $\left(D_{s}\right.$ and $\left.D\right)$ were similar because they have the same physical sense.

Unlike the method used by Vilasboas et al. [12], the tortuosity (W) was not fixed as this is a coefficient directly linked to the microstructure of the analyzed material, which undergoes alteration as the water/cement or water/binder ratio is altered. The mechanical dispersion coefficient $(\alpha)$ was like the results of porosity obtained, showing behavior like that observed by Vilasboas et al. [12].

When the input of chlorides in the cement matrix is evaluated, the mechanical dispersion $\left(D_{m}\right)$ has a priority effect over the dispersion-diffusion (D) because it has a higher input velocity in the studied matrices. This shows that the contaminant penetration through the water flow is more significant than by diffusion, regardless of the microstructure of the tested samples.

\subsubsection{Correlations between results obtained by different testing methods}

The values of the steady-state diffusion coefficients, obtained through ionic migration tests $\left(\mathrm{D}_{\mathrm{s}}\right)$ and column $(\mathrm{D})$ were correlated, according to Figure 12. The adjustment was made to meet the existing physical parameters, where the linear equation generated cannot have a linear coefficient other than 0 (zero).

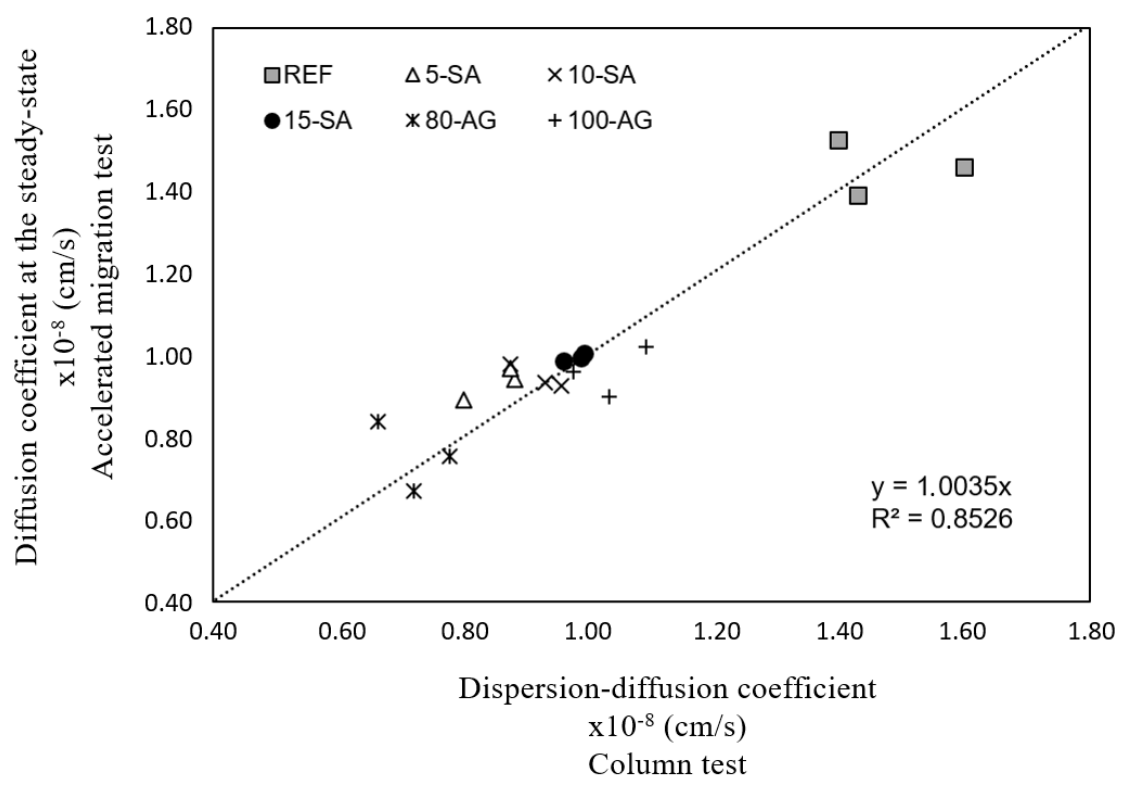

Figure 12. Correlation between ion migration tests and column test.

As observed in Figure 12, the data obtained in both tests have a linear correlation, with a significant determination coefficient $\left(\mathrm{R}^{2}\right)$ of $85.26 \%$. It was also observed that the angular coefficient of the straight-line approaches 1 , which would be the value of "perfect correlation", being equal to 1.0035. This means that besides having a good correlation, the values obtained are practically the same indicating that they represent equivalent parameters, despite being based on very distinct physical and methodological foundations.

This evaluation is also confirmed by Pearson's R test, in which the correlations can present values varying from 1 to -1 , with the value equal to 1 being a perfect and directly proportional correlation, -1 an inverse proportional perfect correlation, and 0 when there is no correlation. For this test, an R approximately equal to 0.94 was found, indicating a strong direct correlation between the evaluated data $(\mathrm{R} \geq 0.70)$.

In addition, a good correlation ( $\mathrm{R}^{2}$ equal to $75.47 \%$ ) between the values obtained from the time lag and the retardation factor was obtained (Figure 13) which, despite being numerically and conceptually distinct, measure the capacity to retain contaminants inside the material studied. Unlike the previous correlation, this adjustment may present a linear coefficient different from 0 (zero), because the minimum value of the retardation factor is equal to 1 (one) and, because they are numerically different parameters, the angular coefficient of the straight line is not close to 1 . 


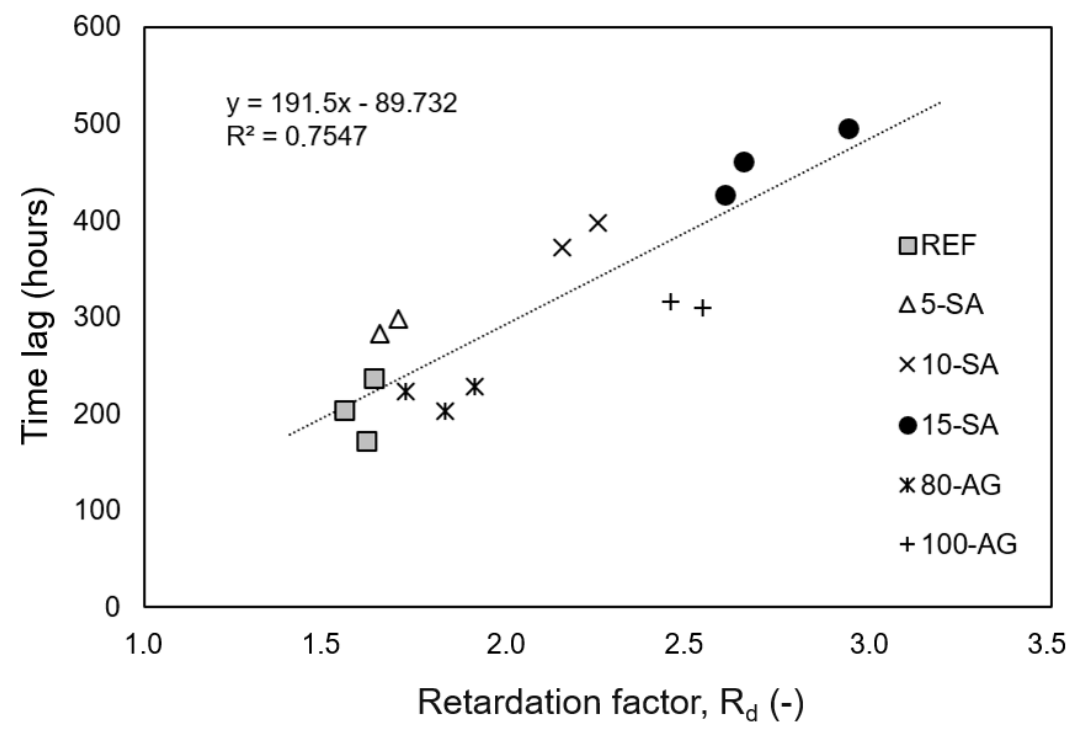

Figure 13. Correlation between time lag and retardation factor.

A linear correlation was only possible by removing data that did not obey a normal distribution. The result obtained with Pearson's R confirms the correlation obtained, it demonstrates a strong direct correlation $(R \geq 0.70)$ with a value approximately equal to 0.87 .

\section{CONCLUSIONS}

Based on the results obtained in this study, it can be concluded that:

- The addition of silica fume to the concrete promoted an increase of up to $126 \%$ in the time lag and reduced the chloride flow, compared to the reference concrete;

- The increase in mortar content resulted in a $49 \%$ increase in the time lag and reduced the flow of chloride ions when compared to the reference concrete;

- Chloride diffusion coefficients are lower because of the increase in mortar content. Similar behavior was observed when silica fume is added in contents up to $10 \%$, indirectly demonstrating the importance of the transition zone for chloride passage in the matrix;

- The parameters $R_{d}$ and time lag have similar meaning that indicate the retention capacity of chloride ions in the matrix. The retardation factor $\left(\mathrm{R}_{\mathrm{d}}\right)$ values obtained in column tests are directly proportional to the time lag values obtained in ionic migration tests, regardless of the mortar or silica fume content;

- In spite of the methodological differences between the column test and the ionic migration test, both are demonstrated to be effective in determining chloride diffusion coefficients in concrete and mortars, presenting a strong correlation between the diffusion values obtained;

- The steady-state diffusion coefficients, obtained through ionic migration tests $\left(D_{s}\right)$ and column (D) presented practically equal values, indicating that they represent equivalent parameters, despite being based on very different physical and methodological foundations;

- The difference in the voltage used in the migration test (12 VDC) did not significantly affect the measured diffusion values. Therefore, this method can be used in durability design;

- As well as being a faster method, the ionic migration test provides important parameters for concrete quality evaluation, such as time lag and ion flow, making it more versatile than the column test.

\section{ACKNOWLEDGEMENTS}

The authors want to thank FAPESB - Bahia Research Foundation and the PPEC/UFBA - Graduate Program in Civil Engineering at the Federal University of Bahia. 


\section{REFERENCES}

[1] U. Angst, B. Elsener, C. K. Larsen, and Ø. Vennesland, "Critical chloride content in reinforced concrete - a review," Cement Concr. Res., vol. 39, pp. 1122-1338, 2009, http://dx.doi.org/10.1016/j.cemconres.2009.08.006.

[2] X. Huang et al., "The effect of supplementary cementitious materials on the permeability of chloride in steam cured high-ferrite Portland cement concrete," Constr. Build. Mater., vol. 197, pp. 99-106, 2019, http://dx.doi.org/10.1016/j.conbuildmat.2018.11.107.

[3] S. M. M. Karein, A. A. Ramezanianpour, T. Ebadi, S. Isapour, and M. Karakouzian, "A new approach for application of silica fume in concrete: Wet granulation," Constr. Build. Mater., vol. 157, pp. 573-581, 2017, http://dx.doi.org/10.1016/j.conbuildmat.2017.09.132.

[4] P. R. L. Helene Corrosão em armaduras para concreto armado, São Paulo, Brasil: Pini, 1986.

[5] D. V. Ribeiro, J. A. Labrincha, and M. R. Morelli, "Effect of the addition of red mud on the corrosion parameters of reinforced concrete," Cement Concr. Res., vol. 42, pp. 124-133, 2012, http://dx.doi.org/10.1016/j.cemconres.2011.09.002.

[6] C. D. Shackelford, "Cumulative mass approach for column testing," J. Geotech. Eng., vol. 121, no. 10, pp. 696-703, 1995, http://dx.doi.org/10.1016/0148-9062(96)85062-5.

[7] C. Andrade, "Calculation of chloride diffusion coeficients in concrete from ionic migration measurements," Cement Concr. Res., vol. 23, pp. 724-742, 1993, http://dx.doi.org/10.1016/0008-8846(93)90023-3.

[8] American Society for Testing and Materials, Standard Test Method for Electrical Indication of Concrete's Ability to Resist Chloride Ion Penetration, ASTM C 1202, 2019.

[9] Nordtest Method. Concrete, Mortar and Cement-Based Repair Materials: Chloride Migration Coefficient from Non-Steady-State Migration Experiments, NT BUILD 492, 1999.

[10]American Society for Testing and Materials, Standard Test Method for Determining the Apparent Chloride Diffusion Coefficient of Cementitious Mixtures by Bulk Diffusion, ASTM C 1556, 2016.

[11] American Society for Testing and Materials, Standard Test Method for Determining the Penetration of Chloride Ion into Concrete by Ponding, ASTM C 1543, 2002.

[12] J. M. L. Vilasboas, S. L. Machado, S. A. Pinto, and J. S. Oliveira "Penetração de cloretos em argamassas e concretos armados: obtenção de parâmetros relativos ao transporte de substâncias solúveis na camada de cobrimento," In $56^{\circ}$ Congr. Bras. Concr., 2014, $16 \mathrm{p}$.

[13] P. Visudmedanukul, M. Kamon, and T. Katsumi, "Chloride transport through cement-bentonite barriers," J. Geotech. Geoenviron. Eng., vol. 133, no. 2, pp. 175-185, 2007, http://dx.doi.org/10.1061/(ASCE)1090-0241(2007)133:2(175).

[14] Associação Brasileira de Normas Técnicas, Concreto endurecido - Determinação do Coeficiente de Permeabilidade à Água, NBR 10786:2013, 2013.

[15] Normalización Española, Durabilidad del Hormigón. Métodos de Ensayo. Determinación de los Coeficientes de Difusión de los iones cloruro en el hormigón endurecido, Método multirrégimen, UNE 83987, 2014.

[16]Associação Brasileira de Normas Técnicas, Cimento Portland - Requisitos, NBR 16697:2018, 2018.

[17]Associação Brasileira de Normas Técnicas, Concreto para Fins Estruturais - Classificação pela Massa Especifica, por Grupos de Resistência e Consistência, NBR 8953:2015, 2015.

[18] X. Shi, N. Xie, K. Fortune, and J. Gong, "Durability of steel reinforced concrete in chloride environments: An overview," Constr. Build. Mater., vol. 30, pp. 125-138, 2012, http://dx.doi.org/10.1016/j.conbuildmat.2011.12.038.

[19] Y. Yue, J. J. Wang, P. A. M. Basheer, and Y. Bai, "Raman spectroscopic investigation of Friedel's salt," Cement Concr. Compos., vol. 86, pp. 306-314, 2018, http://dx.doi.org/10.1016/j.cemconcomp.2017.11.023.

[20]Associação Brasileira de Normas Técnicas, Concreto - Ensaio de Compressão de Corpos de Prova Cilíndricos, NBR 13956-1:2012, 2012.

[21] Associação Brasileira de Normas Técnicas, Agregado Miúdo - Determinação da Massa Específica e Massa Específica Aparente, NBR NM 52:2009, 2009.

[22] Associação Brasileira de Normas Técnicas, Agregado Graúdo - Determinação da Massa Específica, Massa Específica Aparente e Absorção de Água, NBR NM 53:2009, 2009.

[23] Associação Brasileira de Normas Técnicas, Agregados - Determinação da Composição Granulométrica, NBR NM 248:2003, 2003.

[24] Associação Brasileira de Normas Técnicas, Argamassa e Concreto Endurecidos — Determinação da Absorção de Água por Capilaridade, NBR 9779:2012, 2012.

[25] Associação Brasileira de Normas Técnicas, Argamassa e Concreto Endurecidos - Determinação da Absorção de Água, Índice de Vazios e Massa Especifica, NBR 9778:2009, 2009.

[26] American Society For Testing and Materials, Standard Test Methods for Determining Volume Fraction by Sistematic Manual Point Count, ASTM E 562, 2011. 
[27] M. Castellote, C. Andrade, and C. Alonso, "Measurement of the steady and non-steady-state chloride diffusion coefficients in a migration test by means of monitoring the conductivity in the anolyte chamber - Comparison with natural diffusion tests," Cement Concr. Res., vol. 31, pp. 1411-1420, 2001, http://dx.doi.org/10.1016/S0008-8846(01)00562-2.

[28] N. S. Amorim Jr., G. A. O. Silva, C. R. M. Dias, and D. V. Ribeiro, "Concrete containing recycled aggregates: Estimated lifetime using chloride migration test," Constr. Build. Mater., vol. 222, no. 20, pp. 108-118, 2019, http://dx.doi.org/10.1016/j.conbuildmat.2019.06.136.

[29] C. D. Azevedo, C. R. Nascentes, A. T. Matos, and R. F. Azevedo, "Determination of transport parameters for heavy metal in residual compacted soil using two methodologies," Can. J. Civ. Eng., vol. 33, pp. 912-917, 2006, http://dx.doi.org/10.1139/106-038.

[30] C. R. Nascentes, "Estudo da mobilidade de metais pesados em um solo residual compactado," Ph.D. thesis, Univ. Fed. de Viçosa, Viçosa, MG, Brasil, 2006.

[31] J. Bear, Dynamics of Fluids in Porous Media, New York, United States, Dover Publications, 1988.

[32] J. P. V. Costa, N. F. Barros, A. W. Albuquerque, G. Moura Fo., and J. R. Santos, "Fluxo difusivo de fósforo em função de doses e da umidade do solo," Rev. Bras. Eng. Agric. Ambient., vol. 10, no. 4, pp. 828-835, 2006., http://dx.doi.org/10.1590/S141543662006000400007.

[33]C. D. Shackelford, Contaminant transport, Geotechnical Practice For Waste Disposal. United Kingdom: Chapman \& Hall, pp. 3365, 1993.

[34] R. A. Freeze and J. A. Cherry, Groundwater, Englewood Cliffs, USA: Prentice Hall, vol. 12, pp. 145-165, 1979.

[35] L. Huo, T. Qian, J. Hao, and D. Zhao, "Sorption and retardation of strontium in saturated Chinese loess: experimental results and model analysis," J. Environ. Radioact., vol. 116, pp. 19-27, 2013., http://dx.doi.org/10.1016/j.jenvrad.2012.09.002.

[36] R. Siddique, "Utilization of silica fume in concrete: review of hardened properties," Resour. Conserv. Recycl., vol. 55, no. 11, pp. 923-932, 2011, http://dx.doi.org/10.1016/j.resconrec.2011.06.012.

[37]H. F. Campos, N. S. Klein, J. Marques Fo. and M. Bianchini, "Low-cement high-strength concrete with partial replacement of Portland cement with stone powder and silica fume designed by particle packing optimization", J. Clean. Prod., vol. 261, pp. 121228, 2020, http://dx.doi.org/10.1016/j.jclepro.2020.121228.

[38] M. H. F. Medeiros and P. R. L. Helene, "Surface treatment of reinforced concrete in marine environment: Influence on chloride diffusion coefficient and capillary water absorption," Constr. Build. Mater., vol. 23, no. 3, pp. 1476-1484, 2009., http://dx.doi.org/10.1016/j.conbuildmat.2008.06.013.

[39] K. L. Scrivener, A. K. Crumbie, and P. Laugesen, "The Interfacial Transition Zone (ITZ) between cement paste and aggregate in concrete," Interface Sci., vol. 12, pp. 411-421, 2004., http://dx.doi.org/10.1023/B:INTS.0000042339.92990.4c.

[40] R. Talero et al., "Comparative and semi-quantitative XRD analysis of Friedel's salt originating from pozzolan and Portland cement," Constr. Build. Mater., vol. 25, pp. 2370-2380, 2011., http://dx.doi.org/10.1016/j.conbuildmat.2010.11.037.

[41] P. C. Aïtcin, "The durability characteristics of high performance concrete: a review," Cement Concr. Compos., vol. 25, no. 4-5, pp. 409-420, 2003, http://dx.doi.org/10.1016/S0958-9465(02)00081-1.

[42] P. Halamickova, R. Detwler, D. P. Bentz, and E. J. Garboczi, "Water permeability and chloride ion diffusion in Portland cement mortars: relationship to sand content and critical pore diameter," Cement Concr. Res. N. Y., vol. 25, no. 4, pp. 709-802, 1995, http://dx.doi.org/10.1016/0008-8846(95)00069-O.

[43] K. Wu, J. Long, L. Xu, and G. De Schutter, "A study on the chloride diffusion behavior of blended cement concrete in relation to aggregate and ITZ," Constr. Build. Mater., vol. 223, pp. 1063-1073, 2019, http://dx.doi.org/10.1016/j.conbuildmat.2019.07.068.

[44] L. Nilsson, M. H. Ngo, and O. E. Gjørv "High performance repair materials for concrete structures in the Port of Gothenburg," in Proceedings, Second International Conference on Concrete under Severe Conditions - Environment and Loading, London, 1998, pp. 1193-1198.

[45] G. C. Guignone, G. L. Vieira, R. Zulcão, G. Mion, and G. Baptista, "Analysis of the chloride diffusion coefficients by different test methods in concrete mixtures containing metakaolin and high-slag blast-furnace cement," Rev. Materia, vol. 24, no. 4, 2019, http://dx.doi.org/10.1590/s1517-707620190004.0837.

[46] F. K. Sell Jr., G. B. Wally, F. R. Teixeira, and F. C. Magalhães, "Experimental assessment of accelerated test methods for determining chloride diffusion coefficient in concrete," Rev. IBRACON Estrut. Mater., vol. 14, no. 4, pp. e14407, 2021, http://dx.doi.org/10.1590/S1983-41952021000400007.

[47] D. V. Ribeiro, S. A. Pinto, N. S. Amorim Jr., J. S. Andrade No, I. H. L. Santos, S. L. Marques and M. J. S. França, "Effects of binders characteristics and concrete dosing parameters on the chloride diffusion coefficient," Cement Concr. Compos., vol. 122, pp. 104114, 2021, http://dx.doi.org/10.1016/j.cemconcomp.2021.104114.

[48] A. Farahani, H. Taghaddos and M. Shekarchi, "Prediction of long-term chloride diffusion in silica fume concrete in a marine environment," Cement Concr. Compos., vol. 59, pp. 10-17, 2015, http://dx.doi.org/10.1016/j.cemconcomp.2015.03.006.

[49] A. Neville, "Good reinforced concrete in the Arabian Gulf," Mater. Struct., vol. 33, pp. 655-664, 2000., http://dx.doi.org/10.1007/BF02480605. 
[50] M. Shekarchi, A. Rafiee, and H. Layssi, "Long-term chloride diffusion in silica fume concrete in harsh marine climates," Cement Concr. Compos., vol. 31, pp. 769-775, 2009., http://dx.doi.org/10.1016/j.cemconcomp.2009.08.005.

[51] A. Tang and O. C. Sandall, "Diffusion coefficient of chlorine in water at 25-60 ${ }^{\circ}$ C, " Chem. Eng. J., vol. 30, pp. 189-191, 1995, http://dx.doi.org/10.1021/je00040a017.

Author contributions: SAP, SLM and DVR: conceptualization, formal analysis, methodology; SAP: data curation, writing; SLM and DVR: supervision, writing - review.

Editors: Lia Pimentel, Guilherme Aris Parsekian. 